\title{
The Relationship Between Learning Styles with Learning Outcome and Scientific Literacy of Islamic Junior High School (MTs) Students in Mataram
}

\author{
Siti Syifa'un Nufus ${ }^{1 *}$, Gito Hadiprayitno², A Wahab Jufri ${ }^{2}$ \\ ${ }^{1}$ Magister of Science Education Study Program, Universitas Mataram, Indonesia. \\ ${ }^{2}$ Biology Education Study Program, Universitas Mataram, Indonesia. \\ Corresponding author: sitisyifa.azzahra@gmail.com ${ }^{*}$, gitohadiprayitno@unram.ac.id
}

\begin{abstract}
Learning style is one of the important elements in the learning process of students. Information about student learning styles will help teachers design appropriate learning so that students can more easily absorb, organize, and process information during the learning process. Learning in accordance with the character of students in the class will create joyful learning and influences student learning outcomes and abilities, including scientific literacy. This study aims to investigate the relationship between learning styles with student learning outcomes and scientific literacy. This research is descriptive-experimental research. The population of this study was MTs students in Mataram and the subjects of this study were 55 students. In order to determine the tendency of student learning styles, the VARK learning style questionnaire (Visual, Auditory, Read/Write, and Kinesthetic) was developed. In order to assess the scientific literacy that consisted of scientific literacy multiple-choice test and to assess the learning outcome, the final score was employed. Analysis of the relationship between learning styles and the scientific literacy using bivariate correlation, while the effect analysis of learning styles on learning outcomes and scientific literacy using MANOVA and effect analysis of students' scientific literacy on learning outcomes using ANACOVA. The results of the study indicated that the trend of auditory and kinesthetic learning styles correlated significantly with students' scientific literacy $(p<0.05)$, whereas visual and reading/writing learning styles did not significantly correlate ( $p>0.05)$. The type of learning styles does not have a different effect on student learning outcomes and scientific literacy, but scientific literacy has a significant influence on learning outcomes $(p<0.05)$.
\end{abstract}

\section{INTRODUCTION}

Learning style is one of the important elements in the learning process of students. Information about student learning styles will help teachers design appropriate learning so that students can more easily absorb, organize, and process information during the learning process. Learning style is defined as the most sensitive response in a person's brain to receive data or information from information givers and the information-giving environment [1]. Information will be accepted by the brain more quickly if it is in accordance with the learning style [2]. The particular system about an individual's learning preference is known as VARK (visual, auditory, reading/writing, and kinesthetic) popularized by Fleming [3].

There are many models and theories about learning styles. Each individual has a preferred learning style. One particular style is not better than the others and a preferred style does not mean someone cannot learn in other ways, it is simply what may work best to process, learn, and retain information [4].
Students may become better learners if they know their learning style and use their respective strategies. Learning in accordance with the character of students in the class will create joyful learning and influence student learning achievement and abilities, including scientific literacy.

Scientific literacy has been defined in multiple ways, all of which emphasize students' abilities to make use of scientific knowledge in real-world situations [5]. In PISA 2006, it was defined as: " $\ldots$ the capacity to use scientific knowledge or information, to identify questions and to create evidence-based conclusions in order to understand and help make decisions or actions about the natural world and the changes made to it through human activity." [6]. Then, in PISA 2009, scientific literacy is defined as the skill to engage with science-related issues, and with the topic of science, as a reflective person [7].

Currently, scientific literacy is interpreted as the skill to read and comprehend science-related issues and also as the ability to 
understand scientific processes, to apply scientific principles, and to engage meaningfully with scientific information available in daily life [8]. Individuals use scientific information in many real-world conditions beyond the classroom, in ways ranging from evaluating sources of evidence used in media reports about science to recognizing the role and value of science in society to interpreting quantitative information and performing quantitative activities.

Achieving scientific literacy has been proposed as the main goal of science education in many countries [9], as one of the most important skills needed by all young generations in the 21st century [10], [11]. According to [12] reason that higher levels of scientific literacy would tend to increase support for science and provide the public with a more realistic expectation of science education. Some characteristics of scientifically literate person includes: (a) describe phenomena scientifically, (b) evaluate and create scientific enquiry, and (c) interpret data and evidence scientifically [13], [14].

There has been considerable government will and policy attention to increase the quality of education. Scientific literacy has become one of the main objective parts of elementary and secondary education in Indonesia and also is one of the strategic ways to help students achieve optimum learning outcome [15]. Based on the description above, the purpose of this study is to investigate the relationship between learning styles with student learning outcomes and scientific literacy.

\section{RESEARCH METHOD}

$\begin{array}{cclr}\text { This } & \text { research is descriptive- } \\ \text { experimental } & \text { research }\end{array}$ with additional development research at the beginning in three stages, namely preliminary studies, design development, and instrument implementation. The VARK learning styles questionnaire and scientific literacy test developed has gone through a series of expert validation test. At this instrument implementation, there were 55 MTs students in Mataram as subjects of study. The measured learning styles include visual, auditory, read/write, and kinesthetic. 40 multiple-choice-shaped test questions of scientific literacy are spread evenly on each indicator. Student scientific literacy data was obtained from the final score of the test, the total score of all indicators, and in order to assess the learning achievement, the final science score was employed.Analysis of the relationship between learning styles and the scientific literacy using bivariate correlation, while the effect analysis of learning styles on learning outcomes and scientific literacy using MANOVA and effect analysis of students' scientific literacy on learning outcomes using ANACOVA.

\section{RESULT AND DISCUSSION}

\section{The Relationship Between Learning Style Preferences and Students' Scientific Literacy Skills}

Information about the tendency in student learning styles needs to be known by the teacher in order to design joyful learning according to student needs [16]. Interesting and joyful learning will have a positive impact on learning enthusiasm and learning achievement. The VARK questionnaire that has been developed is used to collect data on student learning styles. There are 4 preferences in student learning styles analyzed in this study, namely visual, auditory, reading/writing, and kinesthetic. The results showed that most of the research subjects easily obtained and processed information with a hands-on approach $(47,2 \%)$. In addition, 23,6\% students easily obtained and processed information using a verbal approach. Students who tend to learn in a visual style and $\mathrm{read} / \mathrm{write}$ are $14,6 \%$ students, shown in Figure 1 . 


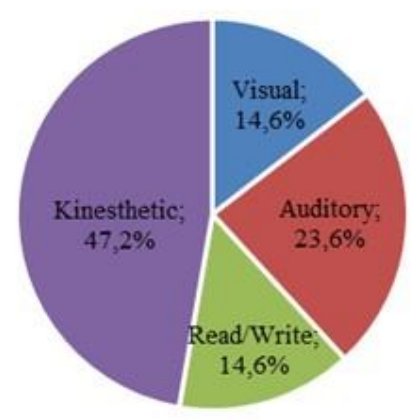

Figure 1. Students' Learning Styles Preferences

Visual learners need to see the teacher's body language and facial expression to fully understand the content of a lesson. They generally prefer to sit at the front of the classroom. These individuals think in pictures and may learn best from visual displays including: diagrams, illustrated textbooks, overhead transparencies, videos, flipcharts, use of interactive whiteboards, and handouts. During a lesson or classroom discussions, visual learners often prefer to take detailed notes to absorb the information [3], [17].

Auditory individuals learn best through verbal lessons, discussions, talking things through, and listening to what others have to say. Auditory learners interpret the underlying meanings of speech through listening to the voice tone, pitch, and speed. These learners often benefit from reading the text and notes out loud and/or listening to recorded notes and information from texts [3], [17], [18]. Individuals with read/write preference prefer information displayed as words. Emphasis is placed on text-based input and output, i.e. reading and writing an all its forms. People who prefer this modality love to work using PowerPoint, the internet, lists, dictionaries, thesauri, and words [3], [18]. The last one, kinesthetic learners, learn best through a handslearning preference to sit still for long periods. Kinesthetic learners can become distracted by their need for movement and activity [3], [17], [18].
Data on students' scientific literacy were obtained using a science literacy test instrument with a total of 40 scientific literacy questions in the form of multiple-choice, while the science learning outcomes were obtained from the final score of even semester. The mapping of scientific literacy abilities and science learning outcomes according to the trends in student learning styles can be seen in the following table.

Table 1. Student' Score on The Scientific Literacy and Learning Achievement

\begin{tabular}{lccc}
\hline $\begin{array}{c}\text { Learning Style } \\
\text { Preferences }\end{array}$ & N & $\begin{array}{c}\text { Scientific Literacy } \\
\text { Average Score }\end{array}$ & $\begin{array}{c}\text { Learning Achievement } \\
\text { Score }\end{array}$ \\
\hline Visual & 8 & 38,75 & 65,62 \\
Auditory & 13 & 45,57 & 67,69 \\
Read/Write & 8 & 45,62 & 65,00 \\
Kinesthetic & 26 & 48,46 & 68,65 \\
\hline
\end{tabular}

These data indicate that students' scientific literacy skills are still low. One of the tests that measure students' scientific literacy is the PISA (Program for International Students Assessment). In 2009, Indonesia was ranked $61^{\text {st }}$ out of 66 countries with an average score of 383 [19]. In 2012, Indonesia's ranking was in $64^{\text {th }}$ position out of 65 with an average score of 382 [20] and on the 2015 PISA test [21] Indonesian students were ranked $63^{\text {rd }}$ out of 72 countries with an average score of 403 . The latest result of PISA in 2018, Indonesia's position declined to position 71 out of 77 countries that took the test with an average score of 382 [22].

The correlation or relationship test was carried out on the learning style preferences (LSP) variable with the students' scientific literacy (SL). Correlation test was carried out on each of the learning style preferences towards students' scientific literacy abilities. The results of the correlation test can be seen in the following tables. 
Table 2. Correlation Test Results. (A) Correlation Of Visual Lsp With Sl; (B) Correlation Between Auditory Lsp And Sl; (C) Correlation Of Reading/Writing Lsp With Sl; And (D) Correlation Between Kinesthetic Lsp And Sl.

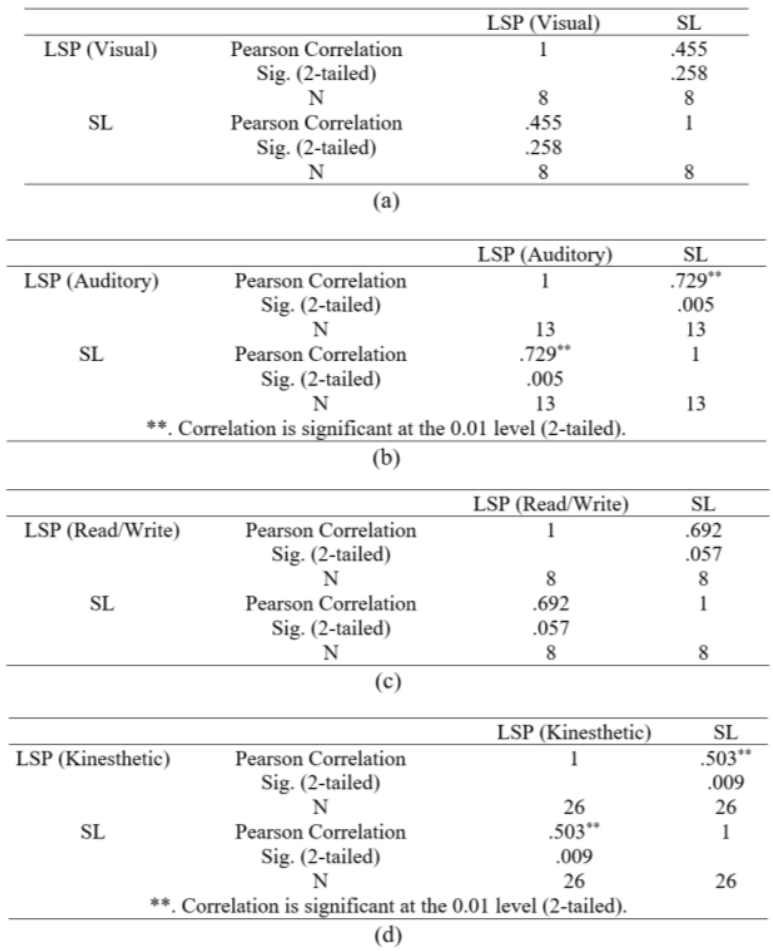

From Table 2 above, it can be seen that the preference of auditory and kinesthetic learning styles has a significant correlation with students' scientific literacy skills ( $\mathrm{p}<0.05$ ), while the preference for visual learning styles and reading/writing is not significantly correlated ( $p>0.05$ ). This is possible because the learning process in the classroom that has been carried out is mostly using lecture (auditory) and practicum (kinesthetic) methods, and also students have not fully recognized their specific learning styles. This was also conveyed by [23], [24], [37]. This is in line with the opinion of [35] that students with kinesthetic learning styles tend to be more active, expressive, and enthusiastic in doing something. It can be said that when students gain an understanding of concepts and are able to implement them through scientific studies, then indirectly the students slowly practice their scientific literacy skills [38]. In this case, the ability to evaluate and design scientific investigations was previously strongly supported by the ability to explain phenomena scientifically [22]. Thus, to maximize efforts to improve scientific literacy skills, teachers can choose learning methods by combining the needs of different student learning styles.

There are several studies related to learning styles that show varied results [39], [40], [41], [42]. This shows that research on learning styles is dynamic and not absolute. Research conducted by [39] shows that in online learning, students who are dominant in visual learning styles and reading/writing have a positive effect on the learning process, while research conducted by [40] shows that students are more dominant with kinesthetic and visual learning styles. However, students with kinesthetic learning style preferences have a positive effect on student learning outcomes, while visual learning styles tend to not. Another study conducted by [41] showed that the study sample was more dominant to be visual and auditory. The kinesthetic and read/write learning style preferences did not have a significant effect. Other research [42] showed that the study sample was more dominant in visual and read/write, but students with auditory learning style preference had better learning outcomes. This provides an opportunity to conduct other research to determine good learning methods, which can accommodate student learning style preferences in class.

2. The Effect of Learning Style Preferences on Student Learning Outcomes and Scientific Literacy Skills

The results showed that there was a significant positive relationship between learning styles (auditory and kinesthetic) and scientific literacy skills. So that further analysis is needed using the Manova test to determine the effect of these learning styles on student 
Jurnal Ilmiah Mandala Education

http://ejournal.mandalanursa.org/index.php/JIME/index

Terakreditasi Peringkat 4 (No. SK: 36/E/KPT/2019)

learning outcomes and scientific literacy abilities.

Table 3. Manova Test Results. (a) Effect of LSP on LO and (b) Effect of LSP on LS

\begin{tabular}{cccccc}
\hline & Sum of Squares & df & Mean Square & F & Sig. \\
\hline Between Groups & 113.108 & 3 & 37.703 & .324 & .808 \\
Within Groups & 5930.529 & 51 & 116.285 & & \\
Total & 6043.636 & 54 & & & \\
\hline \multicolumn{7}{c}{ (a) } \\
\hline \multicolumn{7}{c}{ Sum of Squares } & df & Mean Square & F & Sig. \\
\hline Between Groups & 581.377 & 3 & 193.792 & 1.305 & .283 \\
Within Groups & 7574.760 & 51 & 148.525 & & \\
Total & 8156.136 & 54 & & &
\end{tabular}

From Table 3 it can be seen that the preference of learning styles has no effect on learning outcomes and scientific literacy $(\alpha=$ 0.05 , sig $=0.808$ and $\alpha=0.05$, sig $=0.283$ ). This means that one particular learning style tendency is not better than other learning styles. Each student have learning style preferences that help them to process, study, and store information [3], [18]. Students can become better learners if they know their learning style trends and use their respective strategies [25]. Basically, a learning style is something that students have individually in accepting and understanding a concept, as well as teachers with their respective teaching styles [36], [37]. The good of student learning styles can be used as a material consideration for teachers to determine appropriate learning strategies in instilling important concepts in the students' minds. This result is not in accordance with several previous studies which prove that learning styles have an effect on student learning outcomes [26], [27], [28].

\section{The Effect of Scientific Literacy Skills on Learning Outcomes}

To test the effect between other variables, a test of the effect of scientific literacy on learning outcomes was carried out using the Anacova test. The test results are shown in Table 4 below.

Table 4. Anacova Test

\begin{tabular}{ccccc}
\hline Source & Type III Sum of Squares & df & F & Sig. \\
\hline LO & 2640.494 & 1 & 26.757 & .000 \\
LSP & 377.482 & 3 & 1.275 & .293 \\
\hline
\end{tabular}

The test results in Table 4 show that scientific literacy has a significant effect on student learning outcomes $(\mathrm{p}<0.05)$. This means that students who have good scientific literacy will affect the learning outcomes of science learning in schools. [29], stated that scientific literacy is one of the main needs of students in the 21 st century which will affect the way students think, act, and work. In general, scientific literacy focuses on four interrelated aspects, namely knowledge, context, competence, and attitudes [29], [30]. The knowledge aspect consists of: mastery of the basic material of science, namely physical systems, living systems, and technology systems; knowledge of science that includes understanding inquiry and the ability to provide scientific explanation. Context aspects include personal, social, and historical elements. The competency aspect focuses on the ability to identify science issues, explain scientific phenomena, and use scientific evidence. Meanwhile, the attitude aspect includes interest in science, support for scientific inquiry, selfconfidence, and a sense of responsibility for natural resources and the environment.

According to [29] individual human beings with good scientific literacy have good mastery of the six basic elements of science, namely: (a) science as inquiry, (b) basic science material, (c) science and technology, (d) science in a personal and social perspective, (e) the history and characteristics of science, and (f) the unity of science concepts and processes. Important indicators of scientific literacy to be developed through science learning in schools include thinking skills [29], [30], [31], understanding scientific inquiry [32], [33], and the ability to reason [34], [32]. Based on this opinion, science lessons in schools should be directed to support students so that they can grow and develop into scientific literate humans through their involvement in scientific activities through the inquiry process.

\section{CONCLUSION}

The trend of auditory and kinesthetic learning styles correlated significantly with 
students' scientific literacy, whereas visual and reading/writing learning styles did not significantly correlate. The type of learning styles does not have a different effect on student learning outcomes and scientific literacy, but scientific literacy has a significant influence on learning outcomes. Recommendations that can be given for further research are to determine the appropriate and effective learning models to improve students 'scientific literacy because in this study it was found that students' scientific literacy was quite low.

\section{ACKNOWLEDGMENTS}

The researcher appreciates thanks to the Ministry of Research, Technology and Higer Education for providing funding and assistance for researchers during the study. Researchers also want to express their thanks and appreciation to all parties, who have provided assistance ranging from the development, testing, and publication of this research.

\section{REFERENCES}

1. K. Shah, A. Junaid, S. Nandita, Natarajan, Srikant. How different are students and their learning styles?. International Journal of Research in Medical Sciences (2013) 1. 1. 10.5455/23206012.ijrms20130808.

2. Z. Baykan, Nacar. Learning styles of first-year dental students attending Erciyes University in Kayseri, Turkey. Adv Physiol Edu (2007) 31:15860.

3. N. D. Fleming. I'm different; not dumb. Modes of presentation (VARK) in the tertiary classroom, in Zelmer,A., (ed.) Research and Development in Higher Education, Proceedings of the 1995 Annual Conference of the Higher Education and Research Development Society of Australasia (HERDSA),HERDSA, (1995) Volume 18, pp. 308 $-313$.

4. Y. Alice, A. Kolb, A. David. Learning Styles and Learning Spaces: Enhancing Experiential Learning in Higher Education. AMLE, (2005) 4, 193212, https://doi.org/10.5465/amle.2005.17268566

5. American Association for the Advancement of Science (AAAS). Science for All Americans, New York: Oxford University Press. (1990).

6. Organization for Economic Co-operation and Development. The PISA 2006 Assessment
Framework-Mathematics, Reading, Science and Problem Solving, Knowledge and Skills. (2006)

7. OECD "Science Sample Tasks", in Take the Test: Sample Questions from OECD's PISA Assesments, OECD Publishing, (2009) http://dx.doi.org/10.1787/9782640508155/Retrived, 10August 2020.

8. H. R. Fives. W. Huebner, A. S. Birnbaum, M. Nicolich. "Developing a Measure of Scientific Literacy for Middle School Students" Science Education, 98 (4), 549 - 580 (2014).

9. C. J. Wenning, Assessing nature-of-science literacy as one component of scientific literacy. J. Phys. Tchr. Educ. Online, 3 (4), (2009).

10. A. R. Saavedra, \& V. D. Opfer. Teaching and Learning 21st Century Skills: Lessons from the Learning Sciences. Asia Society, Partnership for Global Learning (2012).

11. L. C. Hiong \& K. Osman. A Conceptual Framework for the Integration of 21st Century Skills in Biology Education Research. Journal of Applied Sciences, Engineering and Technology 6 (16), pp.2976-2983. http://www. maxwellsci.com/ print/rjaset/v6-29762983.pdf. Retrived, 10August 2020 (2013).

12. C. Laugksch, Rüdiger. Scientific Literacy: A Conceptual Overview. Article in Science Education. https://www. researchgate.net/publication/200772545/Retrived: 12August 2020, (2000).

13. C. Gormally, P. Brickman., M. Lutz. Developing a Test of Scientific Literacy Skills (TOSLS): Measuring Undergraduates' Evaluation of Scientific Information and Arguments. CBE-Life Sciences Education. 11, 364-377. (2012).

14. OECD. Education at a Glance 2016: OECD Indicators, OECD Publishing, Paris: http://dx.doi.org/10.187/eag-2016-en/Retrieved: 11August 2020 (2016).

15. A. Okada. Scientific Literacy in the Digital age: Tools, Environments and Resources for Co-inquiry. European Scientific Journal. Special edition 4, 1857 - 7881 (2014).

16. M. Chatib. Gurunya Manusia: menjadikan Semua Anak Istimewa dan Semua Anak Juara. Bandung: Mizan Pustaka. (2016).

17. M. Chatib. Semua Anak bintang: menggali Kecerdasan dan Bakat Terpendam dengan Multiple Intelligences Research (MIR). Bandung: Mizan Pustaka. (2019).

18. S. Kanchi, A. Junaid, S. Nandita, N. Srikant. How different are students and their learning styles?. International Journal of Research in Medical Sciences. (2013). 1. 1. 10.5455/23206012.ijrms20130808.

19. OECD. Results: What Students Know and Can Do Student Performance in Reading, Mathematics and 
Science. (2009). Diunduh dari http://www.oecd.org/pisa/ 2548. pdfpisaproducts/4885. Retrived, 10August 2020.

20. OECD. PISA 2012 Results in Focus. What 15-yearolds Know and What They Can Do with What They Know. (2012). Diunduh dari www.oecd.org/pisa/.../pisa-2012results.htm.Retrived, 10August 2020.

21. OECD. PISA 2015 Results Excellence and Equity in Education, OECD Publishing, Paris. Vol.I. (2015). Diunduh dari http://dx.doi.org/10.1787/ 9789264266490-en. Retrived, 10August 2020.

22. OECD. PISA 2018 Assessment and Analytical Framework, PISA, OECD Publishing, Paris. Volume I. (2019). Diunduh dari https://doi.org/10.1787/7fda7869-en. Retrived, 10August 2020.

23. M. Chatib. Kelasnya Manusia: Memaksimalkan Fungsi Otak belajar Dengan Manajemen Display Kelas. Bandung: Mizan Pustaka. (2015).

24. M. Yaumi. Pembelajaran Berbasis Multiple Intelligences. Jakarta: Dian Rakyat. (2012).

25. B. DePorter, M. Hernacki. Quantum Learning Membiasakan Belajar Nyaman dan Menyenangkan. Bandung: Kaifa Learning. (2013).

26. Gunawan, A. Harjono, Imran. Pengaruh Multimedia Interaktif dan Gaya Belajar Terhadap Penguasaan Konsep Kalor Siswa. Jurnal Pendidikan Fisika Indonesia 12 (2) (2016) 118-125DOI: 10.15294/jpfi.v12i2.5018.

27. I. R. Khoeron, N. Sumarna, T. Permana. Pengaruh gaya Belajar Terhadap Prestasi Belajar Peserta Didik Pada Mata Pelajaran Produktif. Journal of Mechanical Engineering Education, Vol.1, No.2 (2014) pg. $291-297$.

28. M. Y. Soylu. The Effect of Learning Style on Achievement in Different Learning Environments. The Turkish Online Journal of Educational Technology - TOJET October 2009 ISSN: 13036521 volume 8 Issue 4 pg. $43-50$.

29. J. C. Deeming, R. Jacqueline. O’Donnell, J. Christopher. Malone. Scientific Literacy: Resurrecting the Phoenix with Thinking Skills. Science Educator. Winter 2012 Vol. 21, No. 2.

30. A.R. Saavedra, V. D. Opfer. Teaching and Learning 21st Century Skills: Lessons from the Learning Sciences. Asia Society, Partnership for Global Learning. (2013).

31. NEA. 21st Century Knowledge and Skills in Educator Preparation. (2010). Diunduh dari: www.nea.org/home/57601.htm. Retrived, 10August 2020.

32. A. E. Lawson. Promoting Creative and Critical Thinking Skills in College Biology. Bioscience, Volume 27(1) (2001) pp. 13-24.
33. J. Ebenezer, K. Osman, N. Devairakkam, L. Ebenezer. Engaging Students in Environmental Research Projects: Perceptions of Fluency With Innovative Technologies and Levels of Scientific Inquiry Abilities. Journal of Research in Science Teaching Vol. 48, N0. 1, (2011) pp. 94-116.

34. Piraksa, Chakkrapan, P. Phaprom., R. Artdej, N. Srisawasdi. Exploring Scientific Reasoning Ability in Thai University Students: A Case Study of Khon Kaen University, Thailand. ICER 2011: Learning Community for Sustainable Development. (2011). Diunduh dari http//ora.kku.ac.th/db_research /db/8096.pdf. Diakses pada 30 Agustus 2020.

35. A. M. Taiyeb, N. Mukhlisa. Hubungan Gaya Belajar dan Motivasi Belajar dengan Hasil Belajar Biologi Siswa Kelas XI IPA SMA Negeri 1 Tanete Rilau. Bionature Vol. 16, No. 1 (2015).

36. H. Syofyan. Analisis gaya belajar dan motivasi berprestasi terhadap hasil belajar IPA. Jurnal Eduscience Vol. 3, No. 2, (2018) pp. 76-85.

37. N. Nurlia, Y. Hala, R. Muchtar, O. Jumadi, and M. Taiyeb. Hubungan antara gaya belajar, kemandirian belajar, dan minat belajar dengan hasil belajar biologi siswa. Jurnal Pendidikan Biologi Vol. 6, No. 2, (2017)pp. 321-328.

38. U. D. Pertiwi, R. D. Atanti, and R. Ismawati. Pentingnya Literasi Sains Pada Pembelajaran IPA SMP abad 21. Indonesian Journal of Natural Science Education (IJNSE) Vol. 1, No. 1, (2018) pp. 24-29.

39. W. A. Drago and R. J. Wagner. "Vark preferred learning styles and online education", Management Research News, Vol. 27 No. 7, (2004), pp. 113. https://doi.org/10.1108/01409170410784211.

40. R. S. Vaishnav. Learning Styles and Academic Achievement of Secondary School Students. Voice of Research 1 (4) (2013).

41. R. H. Ibrahim and D. Hussein. Assessment of Visual, Auditory, and Kinesthetic Learning Style Among Undergraduate Nursing Students. International Journal of Advanced nursing Studies 5 (1) (2016) pg. 1-4.

42. J. L. Dobson. Learning Style Preferences and Course Performance in an Undergraduate Physiology Class. Advances Physiology Education 308-314 (2009); doi:10.1152/advan.00048.2009. 